\title{
Mechanisms and histopathological impacts of acetamiprid and azoxystrobin in male rats
}

\author{
Heba Nageh Gad EL-Hak ${ }^{1}$ Rasha A. Al-Eisa ${ }^{2}$ - Lamia Ryad ${ }^{3} \cdot$ Ekramy Halawa $^{3}$ - Nahla S. El-Shenawy ${ }^{1}$
}

Received: 20 September 2021 / Accepted: 21 December 2021 / Published online: 29 January 2022

(c) The Author(s) 2021

\begin{abstract}
Acetamiprid (neonicotinoid insecticide) and azoxystrobin (fungicide) are widespread pesticides used for pest management, but they have the potential for toxicity to mammals. The goal of this study was to look for oxidative stress, metabolic alterations, and reproductive problems in male rats' serum after 2 months of exposure to sub-lethal dosages of acetamiprid and azoxystrobin. Seven classes of male rats were formed: control, 3 groups of acetamiprid $\left(1 / 10,1 / 20,1 / 40 \mathrm{LD}_{50}\right)$, and 3 groups of azoxystrobin $\left(1 / 10,1 / 20,1 / 40 \mathrm{LD}_{50}\right)$ and were orally daily treated ( $n=8 /$ group). Our findings revealed that acetamiprid and azoxystrobin disrupted oxidative and metabolic processes in the examined rats throughout 30 and 60 days of testing. The levels of nitric oxide increased significantly, while catalase, a superoxide dismutase enzyme, and glutathione reductase activity were reduced. Serum levels of sex hormones, calcium, and total protein have all dropped substantially in rats. In comparison to the control group, the testis and liver structure, as well as spermatozoa parameters, had distinct histological characteristics. In conclusion, acetamiprid and azoxystrobin exhibit dose- and time-dependent effects on oxidative parameters that cause testis damage.
\end{abstract}

Keywords Lutilizing hormone $\cdot$ Follicle-stimulating hormone $\cdot$ Nitric oxide $\cdot$ Calcium $\cdot$ Sperm count $\cdot$ Male rat

\section{Introduction}

Free radicals called reactive oxygen species (ROS) can infiltrate DNA, causing a unique sequence of DNA changes. The bulk of ROS is made up of the superoxide anion, $\mathrm{H}_{2} \mathrm{O}_{2}$, and singlet oxygen (Butterfield 2020). ROS are considered to be caused mostly by endocrine-disrupting chemicals (EDCs). One of the EDCs was pesticides (Chang et al. 2009; Pouech et al. 2012). Acetamiprid (AC), a neonicotinoid pesticide, binds to postsynaptic nicotinic acetylcholine receptors in insects' central nervous systems (Pohanish 2015).

Responsible Editor: Mohamed M. Abdel-Daim

Nahla S. El-Shenawy

elshenawy_nahla@hotmail.com;

nahla.el-shennawy@science.suez.edu.eg

1 Zoology Department, Faculty of Science, Suez Canal University, Ismailia 41522, Egypt

2 Department of Biology, College of Sciences, Taif University, P.O. Box 11099, Taif 21944, Saudi Arabia

3 Agricultural Research Center, Central Lab of Residue Analysis of Pesticides and Heavy Metals in Food, Giza, Egypt
Azoxystrobin (AZ) is a fungal disease inhibitor used in agriculture (EPA 1997). It acts by blocking electron transport in the mitochondria. There is evidence that ROS has a role in various diseases as a result of inducing oxidative stress (Halliwell 2006). In fruit and vegetable samples, AZ residues equivalent to or below maximum residue levels (MRLs) were found. Values for AZ bioaccumulation potential or biomagnifications have been scarce (Rodrigues et al. 2013). Also, marked immunosuppressive effects were observed for AZ (Naasri et al. 2021).

Antioxidants, including enzymatic and non-enzymatic defense mechanisms, defend against ROS damage. The enzymes' superoxide dismutase (SOD), glutathione (GSH), and catalase (CAT) (Halliwell 2006; Bond and Greenfield 2007), as well as glutathione reductase (GR), are all part of the enzymatic defense system. CAT is an antioxidant enzyme that catalyzes the reduction of $\mathrm{H}_{2} \mathrm{O}_{2}$ to water and can dissolve organic hydroperoxides. CAT uses $\mathrm{H}_{2} \mathrm{O}_{2}$ to oxidize toxins such as phenols, formic acid, formaldehyde, and alcohol (Nazıroğlu 2007). ROS has been shown to damage several ion channels, including calcium channels (Dringen 2005). Excess intracellular $\mathrm{Ca}^{2+}$ levels may thereby trigger CAT breakdown, impair normal mitochondrial function, and result in oxidative stress and bioenergetic failure (Nilius et al. 2008). 
Total protein, albumin, and globulin levels in blood plasma are essential components that assist to maintain osmotic pressure and transporting steroid hormones, lipids, and fibrinogen in blood clotting. Edema is characterized by the movement of fluid from blood arteries into tissues, which is caused by low albumin levels. A lower-than-normal albumin/globulin ratio can suggest problems with the kidneys and hepatocytes (Riris 2017). The presence of phthalate esters on Leydig cells reduced protein levels dramatically (Di Lorenzo et al. 2020). Furthermore, female rats exposed to biphenyl amine had lower blood total protein levels and altered antioxidant enzyme levels (Moustafa and Ahmed 2016). Moreover, dichlorvos causes oxidative stress by releasing ROS (Kanu et al., 2016).

Oxidative stress occurs when the production of harmful chemicals known as free radicals outpaces the antioxidant defenses' ability to protect (Alia et al. 2011). Antioxidant activity is disturbed, indicating a shift in blood cell oxidative state. Following earlier observations (Kapoor et al. 2011), SOD, CAT, and GSH levels increased.

In several species, the $\mathrm{AC}$ has been proven to be harmful to reproduction (Kenfack et al. 2018; Terayama et al. 2018). Arcan et al. (2020) studied the reproductive toxicity of AC in male rats given $12.5 \mathrm{mg} / \mathrm{kg}, 25 \mathrm{mg} / \mathrm{kg}$, or $35 \mathrm{mg} / \mathrm{kg}$ orally for 90 days. Sperm count and plasma testosterone levels both dropped in a dose-dependent manner, according to their findings. GnRH, FSH, and LH levels increased at low and medium dosages, whereas AC induced lipid peroxidation (LPO) and glutathione (GSH) to diminish in the testes. AC increased LPO and nitric oxide (NO) levels of Leydig cells.

In Leydig cells, AC was also discovered to reduce the production of adenosine triphosphate (ATP) and cyclic adenosine monophosphate (cAMP) (Ibrahim et al. 2020). Because A signaling routes are the major signaling mechanisms of steroidogenesis, ROS generated by AC can block the signal pathway, resulting in decreased testosterone production. It reduced the activities of CAT, glutathione peroxidase (GP), and superoxide dismutase (SOD) in mice testes, resulting in excessively high ROS levels (Ibrahim et al. 2020).

According to our knowledge, there is no data available on the toxicity of $\mathrm{AC}$ and $\mathrm{AZ}$ on the hormones and their histopathological effects on the liver and testis. Therefore, the study was concerned with the evaluation of male reproductive toxicity of $\mathrm{AC}$ and $\mathrm{AZ}$ and their mechanisms to confirm whether these compounds can act as EDCs or not.

\section{Material and methods}

\section{Chemical and reagent}

Acetamiprid and azoxystrobin used for the experiment were obtained from Dr. Ehrenstorfer GmbH (Augsburg,
Germany, CHEM Europe. De-ionized water (DIW) was available through a Millipore water purification system.

\section{Experimental design and sample collection}

The experiments were conducted following the European Directive 2010-63-EU (2010) and approved by the Local Ethics Committee at Suez Canal University, Faculty of Science (NO. REC57/2021). Rats were provided by the National Research Centre's (NRC) Animal Breeding House, Dokki, Giza, Egypt. All efforts were made to minimize the suffering and the number of animals used. Fifty-six adult male Wister rats weighing $140-160 \mathrm{~g}$ at age 60-80 days were used. They were kept together under observation for two weeks before the beginning of the experiment for acclimation under standardized conditions. The rats were housed in metal cages at a $24 \pm 3{ }^{\circ} \mathrm{C}$ temperature with normal light conditions (12-h light/dark cycle) and received food and water according to ad libitum feeding practice (Ritskes-Hoitinga et al. 2012).

For dosing reasons, individual standard solutions of $50 \mathrm{mg} / \mathrm{mL} \mathrm{AZ}$ and $3000 \mathrm{~g} / \mathrm{mL}$ AC were prepared weekly in water. The $\mathrm{LD}_{50}$ of $\mathrm{AC}$ was calculated to be $200 \mathrm{mg} / \mathrm{kg}$ (EC 2004; EFSA 2010; Williams 2013), while the EPA estimated the $\mathrm{LD}_{50}$ of azoxystrobin to be $5000 \mathrm{mg} / \mathrm{kg}$ (EPA 1997). After 2 weeks of acclimatization, the animals were divided into seven groups of eight rats, with group 1 serving as the control group. Oral gavage was used daily to provide $(1 / 10,1 / 20$, and $1 / 40) \mathrm{LD}_{50}$ of $\mathrm{AC}(20,10$, and $5 \mathrm{mg} / \mathrm{kg} \mathrm{b}$ wt., respectively) to groups 2,3 , and 4 . The $\mathrm{LD}_{50}$ of $\mathrm{AZ}$ was provided to groups 5,6 , and $7(1 / 10,1 / 20$, and $1 / 40$, respectively) $(500,250$, and $125 \mathrm{mg} / \mathrm{kg} \mathrm{b}$ wt.).

Blood samples were taken either after a month or 2 months. The mix of ketamine and xylazine at a dose of $80-100 \mathrm{mg} / \mathrm{kg}$ and $5-10 \mathrm{mg} / \mathrm{kg}$, respectively, was used as an anesthetic agent and injected intraperitoneal. Blood was collected from the rat's retro-orbital using capillary tubes. Whole blood was placed in an empty tube, allowed to clot, and then centrifuged at $500 \mathrm{xg}$ for $15 \mathrm{~min}$ to obtain serum. For biochemical analysis, the serum was maintained at $-80{ }^{\circ} \mathrm{C}$.

\section{Biomarker determination}

The measurement of serum calcium is based on the formation of a color complex (colorimetric technique) between calcium and o-cresolphtalein in an alkaline medium. The color strength in the sample is proportional to the calcium concentration $(\mathrm{Ng} 2002)$. At a wavelength of $570 \mathrm{~nm}$, the color was measured at a temperature of $37^{\circ} \mathrm{C}$ and the value was presented as $\mathrm{mg} / \mathrm{dL}$. 
In an alkaline medium, proteins form an intense violetblue complex with copper salts. As an antioxidant, iodide is used. The color strength in the assay is proportional to the overall total protein (TP) content (Eckfeldt 1999). The value was calculated using a wavelength of $570 \mathrm{~nm}$ and a temperature of $37^{\circ} \mathrm{C}$, and it was expressed as $\mathrm{mg} / \mathrm{dL}$.

Within 15 min after applying the stop solution, the optical density was read at $450 \mathrm{~nm}$ using an ELISA reader to determine the SOD (Okwakpam and Monanu 2020). The CAT was determined using ELISA (Chelikani et al. 2004).

The biotin-conjugated antibody and enzyme-conjugated Avidin were used to determine GR. The color transition is calculated spectrophotometrically at a wavelength of $450 \mathrm{~nm}$ after the enzyme-substrate reaction is terminated by adding a sulphuric acid solution (Elshal and McCoy 2006).

The detecting antibody was a polyclonal antibody with biotin labeled ELISA Kit, and the pre-coated antibody was Rat NO monoclonal antibody. The color depth of the samples and the testing parameters were highly linked (Report 2014).

\section{Hormonal evaluation}

In this experiment, the competitive inhibition enzyme immunoassay method is employed. On the microtiter plate included in this kit, the goat-anti-rabbit antibody has been pre-coated. Using an antibody specific for luteinizing hormone (LH) and LH conjugated with Horseradish Peroxidase, standards or samples are added to the appropriate microtiter plate wells (HRP). The antibody is used to initiate a competitive inhibitory response between HRP-labeled LH and LH that has not been tagged. Using an ELISA reader, the optical density (OD) was measured at $450 \mathrm{~nm}$ (Report 2014).

The goat-anti-rabbit antibody has been pre-coated on the microtiter plate used in this kit. The antibody is used to start a competitive inhibitory response between FSH that has been HRP labeled and FSH that has not been tagged. Using an ELISA reader, the optical density (OD) was measured at $450 \mathrm{~nm}$ (Report 2014).

\section{Sperm count and mortality determination}

The caudal epididymis was quickly removed from anesthetized rats. The adherent fat, blood vessels, and connective tissue were cut away and the organ from each animal was placed on a hollow plate. The sperm was released by cutting the cauda epididymis longitudinally with a pair of fine-pointed scissors and compressed with forceps and was therefore deposited free of epididymal tissue into the cavity (Adamkovicova et al. 2016).

The sperm suspension was drawn into a white blood cell pipette and diluted to 1:100 with proteolytic enzyme solutions with collagenase (No. C-2139, SIGMA S 1. Louis, MO, USA) or trypsin (DIFCO Detroit, MI, USA) in Ringer's phosphate solution. After this procedure, a final 1:1000 dilution was performed with formaldehyde saline fixative $(1.8 \% \mathrm{NaCI}$ and $2.0 \%$ formalin).

A hemocytometer (BOP NO. 2936-FIO, Arthur H. Thomas Co., Philadelphia, PA, USA) with improved double Neubauer ruling was used for the counting of spermatozoa. Counts for 2-4 hemocytometer chambers were averaged (Adamkovicova et al. 2016). Motion parameters include the percentage of motile spermatozoa (MOT) that was determined, as well as the percentage of mortality.

\section{Histopathological evaluation}

The $10 \%$ formalin was used to fix tissue samples from the liver and testes. Fixed tissues were dehydrated for $30 \mathrm{~min}$ in ascending series of alcohol $(70,80,90,95$, and $100 \%)$ with gentle shaking before being immersed in absolute ethanol overnight. The tissues were soaked in xylene ( 3 times) for $30 \mathrm{~min}$ before being paraffin at $56{ }^{\circ} \mathrm{C}$ (30 min, 3 times). The tissues were embedded in paraffin and cut into $4-\mu \mathrm{m}$ sections using a digital semi-automatic microtome, microtome Ambala (Haryana, India). The samples were mounted on microscope slides, which were then stained for $5 \mathrm{~min}$ with hematoxylin and eosin (Bancroft and Gamble 2013). The stained slides were examined and photographed by using an Axiostar Plus (Carl Zeiss, Göttingen, Germany) microscope adapted with Canon (Pc 1200 Power shoot A641) digital camera using Zoom Browser Ex software at the central lab of Zoology Department, Faculty of Science, Suez Canal University.

\section{Statistical analysis}

The mean and standard error are used to analyze the data. The significance level was set at $P \leq 0.05$ using two-way ANOVA followed by Duncan's multiple range test to estimate the particular difference between pairs of the mean.

\section{Results}

The effects of sub-lethal dosages of AC and AZ were assessed by measuring calcium, proteins, antioxidant enzymes (SOD, CAT, and GR), as well as the NO levels in the rats' serum.

\section{Biochemical evaluation}

Table 1 shows that AC and AZ caused a noticeable difference at high doses in rat serum calcium (Ca) concentration as compared to normal rats. There was a slight and moderate difference induced by low doses. The AC and AZ, 
after 2 months of treatment with 5 and $125 \mathrm{mg} / \mathrm{kg} /$ day, respectively, Ca levels were $11.09 \mathrm{mg} / \mathrm{dL}$ and $12.20 \mathrm{mg} / \mathrm{dL}$, respectively. However, at 20 and $500 \mathrm{mg} / \mathrm{kg} /$ day of $\mathrm{AC}$ and $\mathrm{AZ}$, Ca levels were decreased to be 8.54 and $10.36 \mathrm{mg} / \mathrm{dL}$, respectively, with a Ca concentration of $13.29 \mathrm{mg} / \mathrm{dL}$ for the control group.

At lower dosages of AC and AZ $5 \mathrm{mg} / \mathrm{kg} / \mathrm{day}, 125 \mathrm{mg} / \mathrm{kg} /$ day, serum protein was $8.57 \mathrm{mg} / \mathrm{dL}$ and $9.12 \mathrm{mg} / \mathrm{dL}$, respectively. At high AC and AZ doses, TP levels were $6.75 \mathrm{mg} /$ $\mathrm{dl}$ and $7.71 \mathrm{mg} / \mathrm{dL}$, respectively, while the TP of control animals was $9.58 \mathrm{mg} / \mathrm{dl}$ after 2 months of the treatment (Table 1).

The serum SOD levels were shown to be substantially lower at low dosages of $\mathrm{AC}$ and $\mathrm{AZ}$, at $60.33 \mathrm{mg} / \mathrm{mL}$ and $68 \mathrm{mg} / \mathrm{mL}$, respectively (Table 2). The serum CAT levels were $42.67 \mathrm{mg} / \mathrm{mL}$ and $51.67 \mathrm{mg} / \mathrm{mL}$, respectively, at low dosages of AC and AZ (Table 2). Increasing the doses of $\mathrm{AC}$ and $\mathrm{AZ}$ to $20 \mathrm{mg} / \mathrm{kg} /$ day and $500 \mathrm{mg} / \mathrm{kg} /$ day, CAT levels declined to $31.00 \mathrm{mg} / \mathrm{mL}$ and $38.67 \mathrm{mg} / \mathrm{mL}$, respectively, as compared to control animals $(59.5 \mathrm{mg} / \mathrm{mL})$.

As seen in Table 2, rat serum GR was found to be lower in all doses when compared with the control group. After 2 months, AC ( $5 \mathrm{mg} / \mathrm{kg} / \mathrm{day})$ and AZ $(125 \mathrm{mg} / \mathrm{kg} /$ day) changed the GR level to 36.33 and $43.67 \mathrm{mg} / \mathrm{mL}$, respectively. In comparison to control rats, the $\mathrm{AC}$ and $\mathrm{AZ}$ caused a substantial rise in serum $\mathrm{NO}$ at all doses and during the study (Table 2).

\section{Fertility disorders}

When comparing the $\mathrm{LH}$ and FSH levels after $\mathrm{AC}$ and $\mathrm{AZ}$ treatment to the control rats, the LH levels were significantly lower at both doses (Fig. 1). At low doses of AC and AZ (5 and $125 \mathrm{mg} / \mathrm{kg} /$ day, respectively), LH levels were 20.7 and $25.17 \mathrm{mg} / \mathrm{mL}$. The $\mathrm{LH}$ values were 13.46 and $21.31 \mathrm{mg} /$ $\mathrm{mL}$ at high doses (20 and $500 \mathrm{mg} / \mathrm{kg} /$ day), respectively, as a consequence of $\mathrm{AC}$ and $\mathrm{AZ}$, with a control group of $30.6 \mathrm{mg} / \mathrm{mL}$. Rat FSH values at low doses of AC and AZ, on the other hand, were 2.32 and $3.54 \mathrm{ng} / \mathrm{mL}$, respectively (Fig. 2). At massive doses of AC and AZ (20 and $500 \mathrm{mg} / \mathrm{kg} /$ day, respectively), FSH levels were $1.75 \mathrm{ng} / \mathrm{mL}$ and $2.56 \mathrm{ng} /$ $\mathrm{mL}$, respectively, while the control group's FSH was $4.02 \mathrm{ng} /$ $\mathrm{mL}$ (Fig. 2).

\section{Sperm count and motility}

After 1 and 2 months of treatment, the rat sperm count was slightly lower in AC and AZ treatments. In addition, the

Table 1 Rat's serum calcium and total proteins levels after 1 and 2 months of treatment by AC and AZ doses

\begin{tabular}{|c|c|c|c|c|c|c|c|c|}
\hline \multicolumn{2}{|l|}{ Level (mg/dL) } & \multicolumn{3}{|c|}{ Acetamiprid doses } & \multicolumn{3}{|c|}{ Azoxystrobin doses } & \multirow[t]{2}{*}{ Control } \\
\hline Parameters & Duration & $1 / 10 \mathrm{LD}_{50}$ & $1 / 20 \mathrm{LD}_{50}$ & $1 / 40 \mathrm{LD}_{50}$ & $1 / 10 \mathrm{LD}_{50}$ & $1 / 20 \mathrm{LD}_{50}$ & $1 / 40 \mathrm{LD}_{50}$ & \\
\hline \multirow[t]{2}{*}{ Calcium } & 1st month & $7.32 \pm 0.13^{\mathrm{a}}$ & $8 \pm 0.15^{\mathrm{a}, \mathrm{b}}$ & $9.91 \pm 0.18^{\mathrm{a}, \mathrm{b}}$ & $9.16 \pm 0.15^{\mathrm{a}}$ & $10.03 \pm 0.15^{\mathrm{a}, \mathrm{b}}$ & $11 \pm 0.18^{\mathrm{a}, \mathrm{b}}$ & $12.02 \pm 0.06$ \\
\hline & 2nd month & $8.54 \pm 0.12^{a}$ & $9.18 \pm 0.14^{\mathrm{a}, \mathrm{b}}$ & $11.09 \pm 0.17^{\mathrm{a}, \mathrm{b}}$ & $10.36 \pm 0.15^{a}$ & $11.09 \pm 0.17^{\mathrm{a}, \mathrm{b}}$ & $12.20 \pm 0.16^{\mathrm{a}, \mathrm{b}}$ & $13.29 \pm 0.12$ \\
\hline \multirow[t]{2}{*}{ Total proteins } & 1st month & $5.25 \pm 0.09^{a}$ & $5.79 \pm 0.11^{\mathrm{a}, \mathrm{b}}$ & $7.07 \pm 0.08^{\mathrm{a}, \mathrm{b}}$ & $6.21 \pm 0.14^{\mathrm{a}}$ & $6.96 \pm 0.12^{\mathrm{a}, \mathrm{b}}$ & $7.62 \pm 0.07^{\mathrm{a}, \mathrm{b}}$ & $8.06 \pm 0.03$ \\
\hline & 2nd month & $6.75 \pm 0.09^{\mathrm{a}}$ & $7.33 \pm 0.08^{\mathrm{a}, \mathrm{b}}$ & $8.57 \pm 0.08^{a, b}$ & $7.71 \pm 0.14^{\mathrm{a}}$ & $8.46 \pm 0.12^{\mathrm{a}, \mathrm{b}}$ & $9.12 \pm 0.07^{\mathrm{a}, \mathrm{b}}$ & $9.58 \pm 0.01$ \\
\hline
\end{tabular}

Data presented as mean \pm S.E. ${ }^{a}$ Significant difference $(1 / 10,1 / 20,1 / 40) \mathrm{LD}_{50}$ as compared to the control group, and ${ }^{\mathrm{b}}$ significant difference as compared to the $1 / 10 \mathrm{LD}_{50}$ group $(n=4)$

Table 2 Rat's serum oxidative/antioxidant biomarkers levels after 1 and 2 months of treatment by AC and AZ doses

\begin{tabular}{|c|c|c|c|c|c|c|c|c|}
\hline \multicolumn{2}{|c|}{$\begin{array}{l}\text { Oxidative/antioxidant param- } \\
\text { eters }\end{array}$} & \multicolumn{3}{|c|}{ Acetamiprid doses } & \multicolumn{3}{|c|}{ Azoxystrobin doses } & \multirow[t]{2}{*}{ Control } \\
\hline Levels (mg/mL) & Duration & 1/10 LD50 & 1/20 LD50 & 1/40 LD50 & 1/10 LD50 & 1/20 LD50 & 1/40 LD50 & \\
\hline \multirow[t]{2}{*}{ Catalase } & $1^{\text {st }}$ month & $35 \pm 1.15^{\mathrm{a}}$ & $41.33 \pm 1.45^{\mathrm{a}, \mathrm{b}}$ & $46.67 \pm 1.20^{\mathrm{a}, \mathrm{b}}$ & $42.67 \pm 1.45^{\mathrm{a}}$ & $42.67 \pm 1.15^{\mathrm{a}, \mathrm{b}}$ & $52.33 \pm 0.20^{\mathrm{a}, \mathrm{b}}$ & $55.5 \pm 0.29$ \\
\hline & $2^{\text {nd }}$ month & $31 \pm 1.15^{\mathrm{a}}$ & $37.33 \pm 0.88^{\mathrm{a}, \mathrm{b}}$ & $42.67 \pm 1.20^{\mathrm{a}, \mathrm{b}}$ & $38.67 \pm 1.45^{\mathrm{a}}$ & $45 \pm 1.15^{\mathrm{a}, \mathrm{b}}$ & $51.67 \pm 0.88^{\mathrm{a}, \mathrm{b}}$ & $59.5 \pm 0.29$ \\
\hline \multirow{2}{*}{$\begin{array}{l}\text { Superoxide dis- } \\
\text { mutase }\end{array}$} & $1^{\text {st }}$ month & $46.67 \pm 1.86^{\mathrm{a}}$ & $55.67 \pm 1.76^{\mathrm{a}, \mathrm{b}}$ & $65.33 \pm 1.45^{\mathrm{a}, \mathrm{b}}$ & $58 \pm 1.53^{\mathrm{a}}$ & $68 \pm 0.58^{a, b}$ & $70.40 \pm 0.31^{\mathrm{a}, \mathrm{b}}$ & $74.67 \pm 0.88$ \\
\hline & $2^{\text {nd }}$ month & $41.67 \pm 1.86^{\mathrm{a}}$ & $49 \pm 0.88^{\mathrm{a}, \mathrm{b}}$ & $60.33 \pm 1.45^{\mathrm{a}, \mathrm{b}}$ & $53 \pm 1.52^{\mathrm{a}}$ & $63 \pm 0.8^{\mathrm{a}, \mathrm{b}}$ & $68 \pm 1.15^{\mathrm{a}}$ & $77.5 \pm 0.29$ \\
\hline \multirow{2}{*}{$\begin{array}{l}\text { Glutathione reduc- } \\
\text { tase }\end{array}$} & $1^{\text {st }}$ month & $28.67 \pm 0.88^{\mathrm{a}}$ & $35.33 \pm 1.45^{\mathrm{a}, \mathrm{b}}$ & $40.8 \mathrm{o} \pm 0.42^{\mathrm{a}, \mathrm{b}}$ & $40 \pm 0.58^{a}$ & $43.50 \pm 0.29^{\mathrm{a}, \mathrm{b}}$ & $45.27 \pm 0.37^{\mathrm{a}, \mathrm{b}}$ & $48.5 \pm 0.29$ \\
\hline & $2^{\text {nd }}$ month & $23.67 \pm 0.88^{\mathrm{a}}$ & $30.33 \pm 1.45^{\mathrm{a}, \mathrm{b}}$ & $36.33 \pm 0.88^{\mathrm{a}, \mathrm{b}}$ & $35.67 \pm 1.20^{\mathrm{a}}$ & $40 \pm 0.58^{\mathrm{a}, \mathrm{b}}$ & $43 \pm 0.67^{\mathrm{a}, \mathrm{b}}$ & $55.5 \pm 0.29$ \\
\hline \multirow[t]{2}{*}{ Nitric oxide } & $1^{\text {st }}$ month & $72.33 \pm 0.58^{\mathrm{a}}$ & $64.33 \pm 0.88^{\mathrm{a}, \mathrm{b}}$ & $57.67 \pm 0.95^{\mathrm{a}, \mathrm{b}}$ & $57 \pm 0.88^{a}$ & $45.67 \pm 0.87^{\mathrm{a}, \mathrm{b}}$ & $40.33 \pm 0.88^{a, b}$ & $33 \pm 0.58$ \\
\hline & $2^{\text {nd }}$ month & $76.33 \pm 0.88^{a}$ & $68.33 \pm 0.88^{\mathrm{a}, \mathrm{b}}$ & $61.67 \pm 0.88^{\mathrm{a}, \mathrm{b}}$ & $61.67 \pm 0.88^{a}$ & $49.67 \pm 0.88^{\mathrm{a}, \mathrm{b}}$ & $44 \pm 0.58^{\mathrm{a}, \mathrm{b}}$ & $36.9 \pm 0.08$ \\
\hline
\end{tabular}

Data presented as mean \pm S.E $(n=4) .{ }^{\text {a }}$ Significant difference of $1 / 10,1 / 20$, and $1 / 40 \mathrm{LD}_{50}$ as compared to the control group, ${ }^{\mathrm{b}}$ significant difference as compared to the $1 / 10 \mathrm{LD}_{50}$ group 


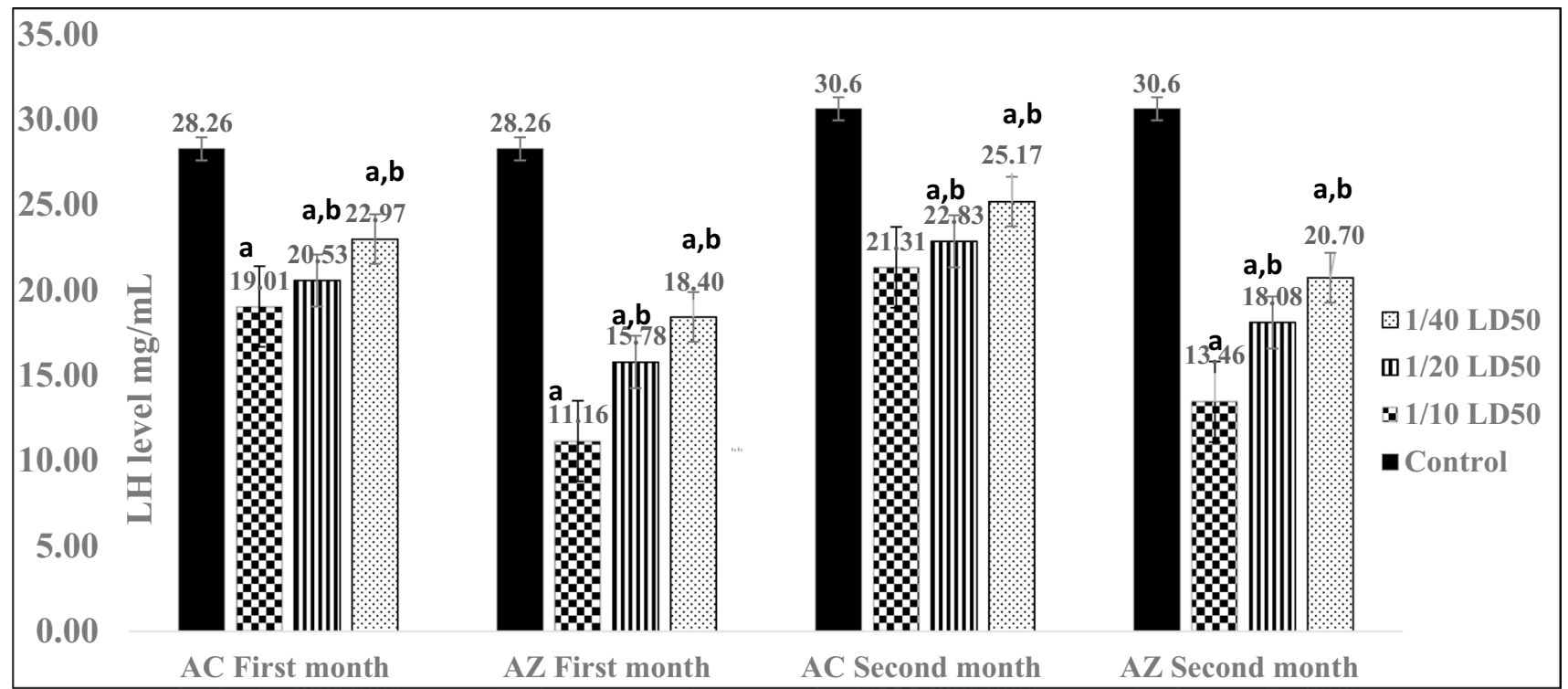

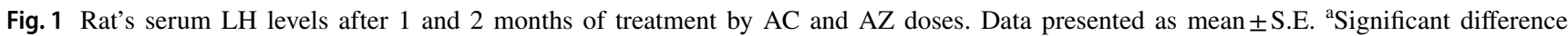
$(1 / 10,1 / 20,1 / 40) \mathrm{LD}_{50}$ as compared to the control group, ${ }^{\mathrm{b}}$ significant difference as compared to the $1 / 10 \mathrm{LD}_{50}$ group $(n=4)$

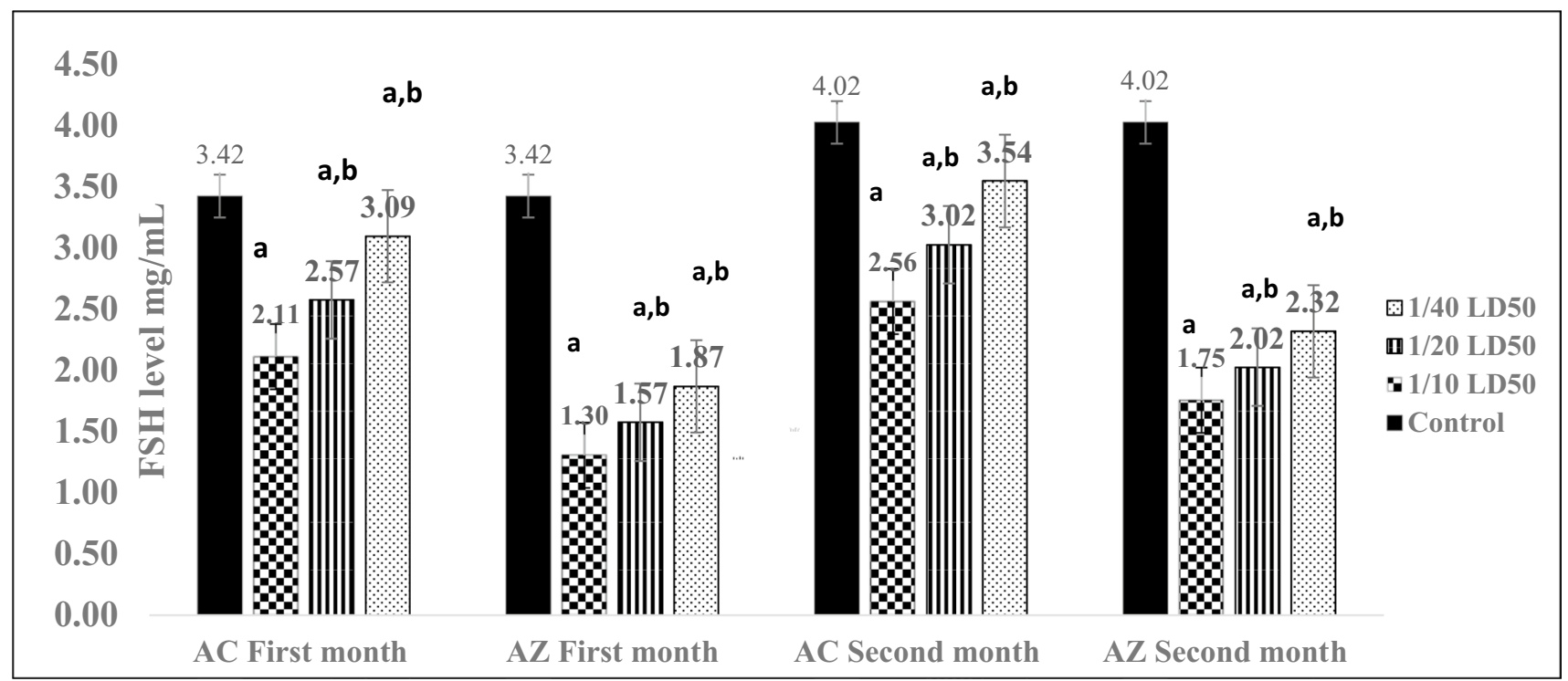

Fig. 2 Rat's serum FSH levels after 1 and 2 months of treatment by AC and AZ doses. Data presented as mean \pm S.E. ${ }^{a}$ significant difference $(1 / 10,1 / 20,1 / 40) \mathrm{LD}_{50}$ as compared to the control group, ${ }^{\mathrm{b}}$ significant difference as compared to the $1 / 10 \mathrm{LD}_{50} \operatorname{group}(n=4)$

second-month findings changed significantly from the firstmonth results (Table 3). However, $1 / 10,1 / 20$, and $1 / 40 \mathrm{LD}_{50}$ AC doses resulted in sperm counts of $84,90.33$, and 96.67 million/mL, respectively, compared to a control rat count of $111 \mathrm{million} / \mathrm{mL}$.

However, the sperm counts after $1 / 10,1 / 20$, and $1 / 40$ $\mathrm{LD}_{50} \mathrm{AZ}$ doses were $93.33,98$, and 101.67 million/mL, respectively, in the first month. The sperm count was 87.33 , 93.67, and 98.33 million/mL, respectively, after separate doses of 1/10,1/20, and $1 / 40 \mathrm{LD}_{50} \mathrm{AC}$, compared to a control animal count of 120 million/mL. The sperm count at the end of the second month was 91, 99, and 106 million/ $\mathrm{mL}$, respectively, as a result of $1 / 10,1 / 20$, and $1 / 40 \mathrm{LD}_{50}$ AZ (Table 3).

After 1 and 2 months of treatment, the motility of rat sperm was dramatically reduced as the concentration of the two pesticides increased relative to the control group (Table 3). In addition, the second-month findings differed 
Table 3 Rat's sperm count and motility after 1 and 2 months of treatment by AC and AZ doses

\begin{tabular}{|c|c|c|c|c|c|c|c|c|}
\hline \multicolumn{2}{|l|}{ Semen evaluation } & \multicolumn{3}{|c|}{ Acetamiprid doses } & \multicolumn{3}{|c|}{ Azoxystrobin doses } & \multirow[t]{2}{*}{ Control } \\
\hline Sperm & Duration & $1 / 10 \mathrm{LD}_{50}$ & $1 / 20 \mathrm{LD}_{50}$ & $1 / 40 \mathrm{LD}_{50}$ & $1 / 10 \mathrm{LD}_{50}$ & $1 / 20 \mathrm{LD}_{50}$ & $1 / 40 \mathrm{LD}_{50}$ & \\
\hline \multirow{2}{*}{$\begin{array}{l}\text { Count (million/ } \\
\mathrm{mL} \text { ) }\end{array}$} & $1^{\text {st }}$ month & $84 \pm 1.15^{\mathrm{a}}$ & $90.33 \pm 0.88^{\mathrm{a}, \mathrm{b}}$ & $96.67 \pm 0.88^{\mathrm{a}, \mathrm{b}}$ & $93.33 \pm 0.88^{a}$ & $98 \pm 1.15^{\mathrm{a}, \mathrm{b}}$ & $101.67 \pm 1.45^{\mathrm{a}, \mathrm{b}}$ & $110.67 \pm 1.76$ \\
\hline & $2^{\text {nd }}$ month & $87.33 \pm 0.67^{\mathrm{a}}$ & $93.67 \pm 0.88^{a, b}$ & $98.33 \pm 1.20^{\mathrm{a}, \mathrm{b}}$ & $91 \pm 1.0^{\mathrm{a}}$ & $99 \pm 0.58^{\mathrm{a}, \mathrm{b}}$ & $106 \pm 1.15^{\mathrm{a}, \mathrm{b}}$ & $120 \pm 1.15$ \\
\hline \multirow[t]{2}{*}{ Motility (\%) } & $1^{\mathrm{st}}$ month & $73.33 \pm 0.88^{a}$ & $76.33 \pm 0.88^{a, b}$ & $79 \pm 0.58^{\mathrm{a}, \mathrm{b}}$ & $80.67 \pm 0.67^{\mathrm{a}}$ & $87 \pm 1.0^{\mathrm{a}, \mathrm{b}}$ & $92.33 \pm 0.88^{\mathrm{a}, \mathrm{b}}$ & $90.33 \pm 0.88$ \\
\hline & $2^{\text {nd }}$ month & $68 \pm 1.15^{\mathrm{a}}$ & $73 \pm 1.73^{\mathrm{a}, \mathrm{b}}$ & $78.67 \pm 0.88^{a, b}$ & $76 \pm 1.15^{\mathrm{a}}$ & $82.33 \pm 1.45^{\mathrm{a}, \mathrm{b}}$ & $87.67 \pm 1.20^{\mathrm{a}, \mathrm{b}}$ & $90.67 \pm 1.20$ \\
\hline
\end{tabular}

Data presented as mean \pm S.E. ${ }^{a}$ significant difference $(1 / 10,1 / 20,1 / 40) \mathrm{LD}_{50}$ as compared to the control group, ${ }^{\mathrm{b}}$ significant difference as compared to the $1 / 10 \mathrm{LD}_{50}$ group ( $n=8$ /group; $n=4$ at each time)

significantly from the first-month results. In the first month, sperm motility was $73.33 \%, 76.33 \%$, and $79 \%$, respectively, as a result of $1 / 10,1 / 20$, and $1 / 40 \mathrm{LD}_{50} \mathrm{AC}$, with a control rat count of $90 \%$. After a month, the sperm motility percentages as a result of $1 / 10,1 / 20$, and $1 / 40 \mathrm{LD}_{50} \mathrm{AZ}$ doses were $80.67 \%, 87 \%$, and $92.33 \%$, respectively. In comparison to a control sample, the second-month results after separate doses of $1 / 10,1 / 20$, and $1 / 40 \mathrm{LD}_{50} \mathrm{AC}$ were $68 \%, 73 \%$, and $78.67 \%$, respectively. In comparison to control rats, sperm motility in the second month was $76 \%, 82.33 \%$, and $87.67 \%$ as a result of $1 / 10,1 / 20$, and $1 / 40 \mathrm{LD}_{50} \mathrm{AZ}$ doses, respectively (Table 3 ).

\section{Histopathological observation}

The histopathological results of the liver and testes for each group of treatment of $\mathrm{AC}$ and $\mathrm{AZ}$ are represented in Figs. 3 and 4, respectively. There were no variations in the histopathological severity between the groups' treatments.

The livers of the control group showed no histopathological alterations. The control liver tissue was histologically examined and revealed normal large hexagonal hepatocytes organized into cords radiating around the central vein and portal region. Blood sinusoids separate each cord of hepatocytes from the others (Fig. 3A and B).

Histopathological variations in the liver of $\mathrm{AC}$ (Fig. 3C-E) and AZ-treated classes (Fig. 3F-H) displayed portal mononuclear cell invasion, hydropic degeneration, and congestion of the central vein and hepatic artery, as well as veins that seemed dilated. Following AZ treatment, the liver undergoes significant histopathological changes. In the low-and high-dose groups of $\mathrm{AC}$ and $\mathrm{AZ}$, edema and eosinophilia were found in the tissue (Fig. 3G-H).

The control group's testis had a normal testicular histological structure and usual spermatogenesis. The ordered development from spermatogonia to spermatocytes with groups of spermatids and mature spermatozoa is seen in the seminiferous tubules with the usual thin basement membrane as well as the standard germinal epithelium (Fig. 4A). The number of spermatogenic cells has decreased with vacuole shape, spermatids, and certain cells sloughed into the lumen of the seminiferous tubules at all doses of AC (Fig. 4B-D) or AZ (Fig. 4E-G).

The effect of different doses of acetamiprid and azoxystrobin on the germinal epithelium has been measured to prove the decrease in the spermatogenic cells (Fig. 5).

There was a significnant differences in germinal tissue in all treated groups compared to the control.

\section{Discussion}

After a month and 2 months of $\mathrm{AC}$ and $\mathrm{AZ}$ treatment, the serum Ca, SOD, CAT, GR, NO, LH, and FSH levels, as well as histopathological alterations in the liver and testis were assessed. The effect of AC and AZ were estimated on sperm counting and their motility.

The rat serum Ca was impaired by $\mathrm{AC}$ and $\mathrm{AZ}$, and at elevated doses, $\mathrm{AC}$ and $\mathrm{AZ}$ caused a noticeable deviation from the control group. The $\mathrm{Ca}$ levels were greatly reduced at 20 and $500 \mathrm{mg} / \mathrm{kg} /$ day of $\mathrm{AC}$ and $\mathrm{AZ}$, respectively. This finding has previously been confirmed, while the equilibrium of bone formation and $\mathrm{Ca}$ homeostasis is influenced by both endogenous and exogenous influences (Ronis et al. 2020) Also, etoxazole, an oxazoline pesticide, induced a deficiency in Ca homeostasis (Ham et al. 2020).

During uremia, calcium synthesis is disrupted, which contributes to the progression of secondary hyperparathyroidism of the kidneys in monogastric patients (Kaneko and Tomino 1999). Analytically imperceptible hypocalcemia was observed in renal dysfunction, which may be a direct physiochemical consequence of hyperphosphatemia, a lack of active sources of vitamin D, or both. Hypocalcemia causes the release of parathyroid hormone, which raises the blood calcium level (Mondal et al. 2019).

In the current study, TP levels declined in a dosedependent manner. This result was matched with previous observations. For example, the serum TP of male rats significantly decreased when exposed to phthalate esters (Di Lorenzo et al. 2020); additionally, the serum TP of female rats was considerably lower when exposed to biphenyl amine (Moustafa and Ahmed 2016; Di Lorenzo et al. 2020). 


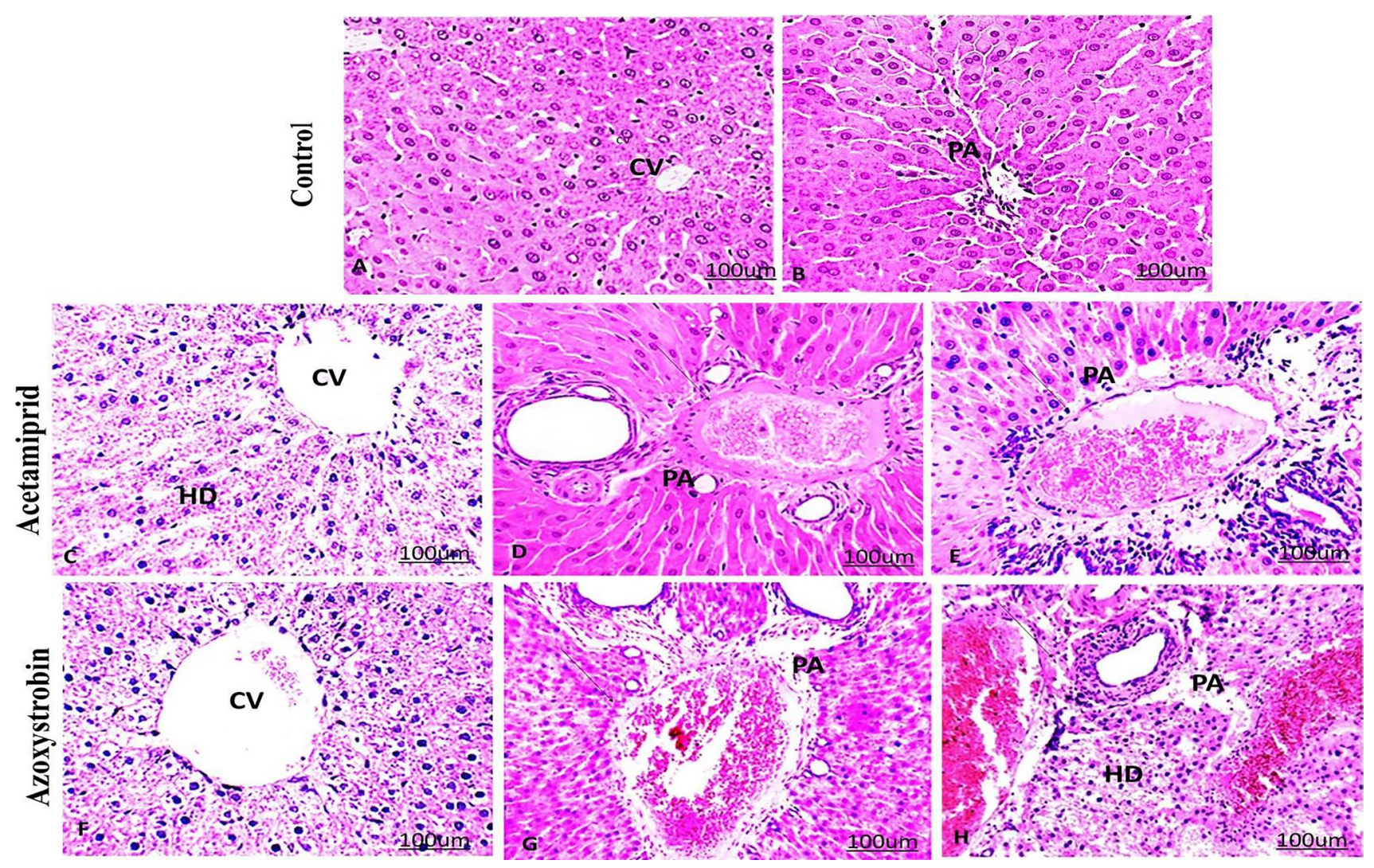

Fig. 3 Effect of acetamiprid and azoxystrobin on liver tissue of rats. A, B Histological sections of the liver of control rats showed normal liver central vein $(\mathrm{CV})$ and a normal portal area (PA). Liver sections of the treated group with acetamiprid with different doses $(\mathbf{C}-\mathbf{E})$. C Low dose demonstrated hydropic degeneration (HD), D medium dose demonstrated infiltration of mononuclear cells (arrow), hypertrophied and edema of portal area (PA), $\mathbf{E}$ high dose demonstrated infiltration

In the current findings, protein loss could be due to structural protein lysis, which is visible histologically as hepatocellular membrane disruption. These data are in coincidence with Bhushan et al. (2013) who found that cypermethrin and beta-cyfluthrin depleted TP levels and caused hepatocellular damage. Also, it may occur due to a disturbance in protein metabolism as a result of a reduction in protein synthesis or elevation of proteolytic activity or degradation (Uboh et al., 2009). Furthermore, the negative effects of ROS created by $\mathrm{AC}$ exposure on proteins oxidized in the liver may cause the TP drop. Although neonicotinoid pesticides have a variety of modes of action, they induce oxidative stress by inhibiting antioxidants and causing the formation of ROS (Çavaş et al., 2014).

The cellular enzymatic antioxidant protection mechanism defends biological structures from ROS by controlling the formation of free radicals and their metabolites in normal cells (Patlevič et al. 2016). The most effective antioxidant enzymes in the struggle against superoxide radicals are SOD, CAT, and GR. The dismutation of superoxide into of mononuclear cells (arrow), hypertrophied and edema of portal area (PA). Liver sections of the treated group with azoxystrobin $(\mathrm{F}-\mathrm{H})$. F; low dose demonstrated hydropic degeneration (HD). G Medium dose demonstrated infiltration of mononuclear cells (arrow), hypertrophied, and edema of portal area (PA). H High dose demonstrated infiltration of mononuclear cells (arrow), hypertrophied, and edema of portal area (PA). (hematoxylin-eosin (H\&E) stained, $\times 200$ )

oxygen and $\mathrm{H}_{2} \mathrm{O}_{2}$ is catalyzed by SOD (Patlevič et al. 2016). $\mathrm{CAT}$ is a heme-containing peroxisomal enzyme that plays a role in the breakdown of intracellular $\mathrm{H}_{2} \mathrm{O}_{2}$. The GR is another important antioxidant enzyme that uses NADPH to convert glutathione disulfide to sulfhydryl type glutathione. These enzymes work together in the ROS metabolic pathway to eliminate the oxidative stress effects (Rives et al. 2020).

The AC generated oxidative damage and impaired the liver, altering cholesterol levels, alanine aminotransferase, and aspartate aminotransferase enzymes (Karaca et al. 2019). Furthermore, at doses of 26.25 and $105 \mathrm{mg} / \mathrm{kg}$ for 28 days in Wistar rats, it caused LPO and diminished GSH production in the kidney and liver (Doltade et al. 2019). In the livers of rats exposed to higher doses of AC, Chakroun et al. (2016) found a statistically significant decline in SOD and CAT, as well as an increase in LPO. After sub-acute exposure to $\mathrm{AC}$, similar findings were obtained in the testis of mice (Zhang et al. 2011).

Previous research showed a sliver of data and demonstrated the mechanism of EDC-induced induction of toxic effects. 


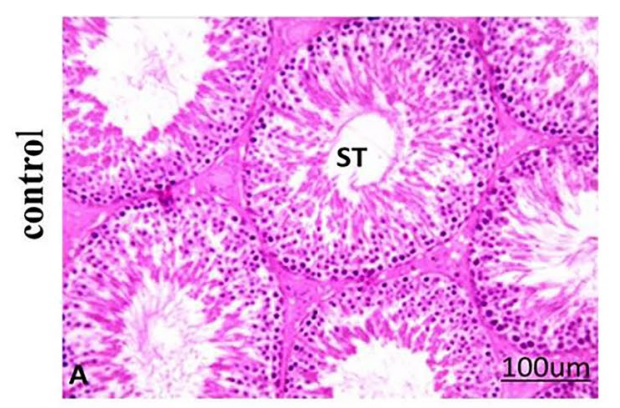

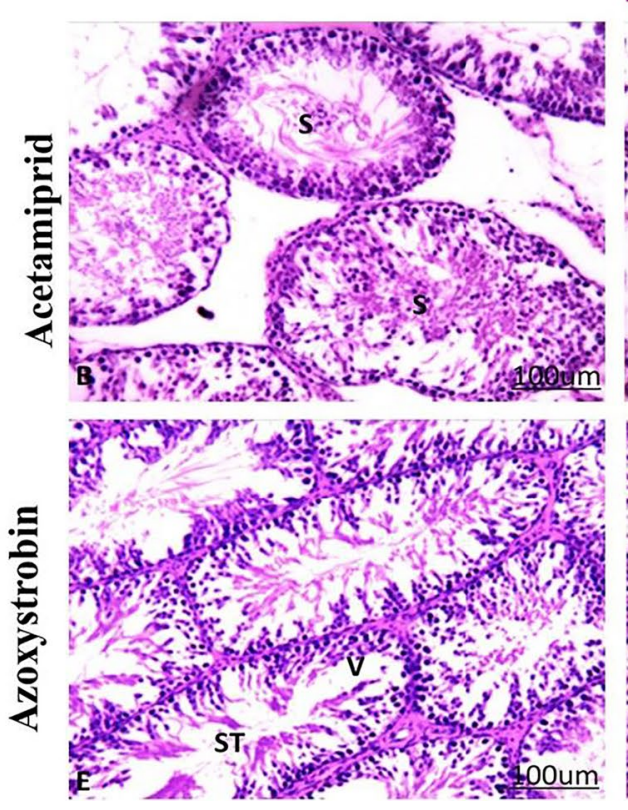
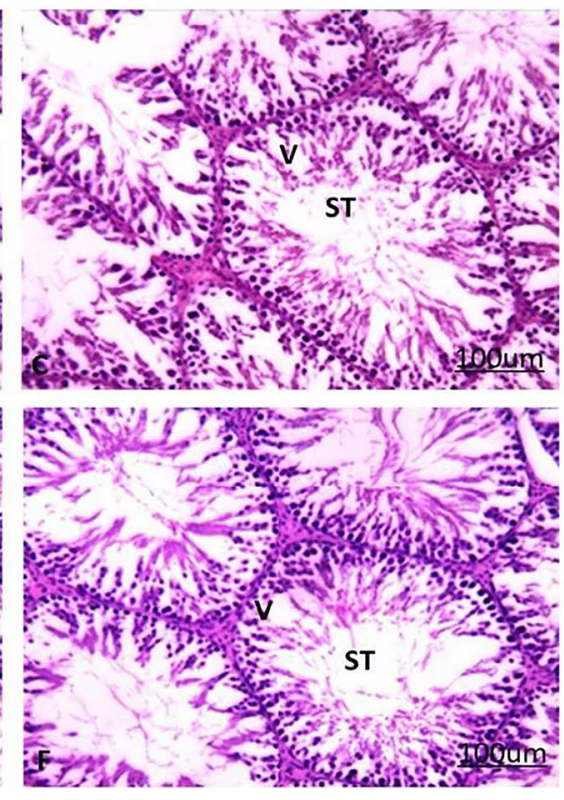

Fig. 4 Effect of acetamiprid and azoxystrobin on testis tissue of rats. A Seminiferous tubules (ST) in the control group showed a normal appearance. A photomicrograph of seminiferous tubules (ST) of the treated group with acetamiprid. B Low dose demonstrated sloughing of germinal epithelium (S). C Medium dose demonstrated degenerated spermatogenic cells with vacuole formation (V). D High dose demonstrated degenerated spermatogenic cells with vacuole forma- tion (V). Seminiferous tubules (ST) of the treated group with Azoxystrobin. E Low dose demonstrated degenerated spermatogenic cells with vacuole formation (V). F Medium dose demonstrated degenerated spermatogenic cells with vacuole formation (V). G High dose demonstrated degenerated spermatogenic cells with vacuole formation $(V)$. (hematoxylin-eosin $(H \& E)$ stained, $\times 200)$
Fig. 5 Effect of different doses of acetamiprid and azoxystrobin on the germinal epithelium. ${ }^{\text {a }}$ Significant difference $(1 / 10$, $1 / 20,1 / 40) \mathrm{LD}_{50}$ as compared to the control group

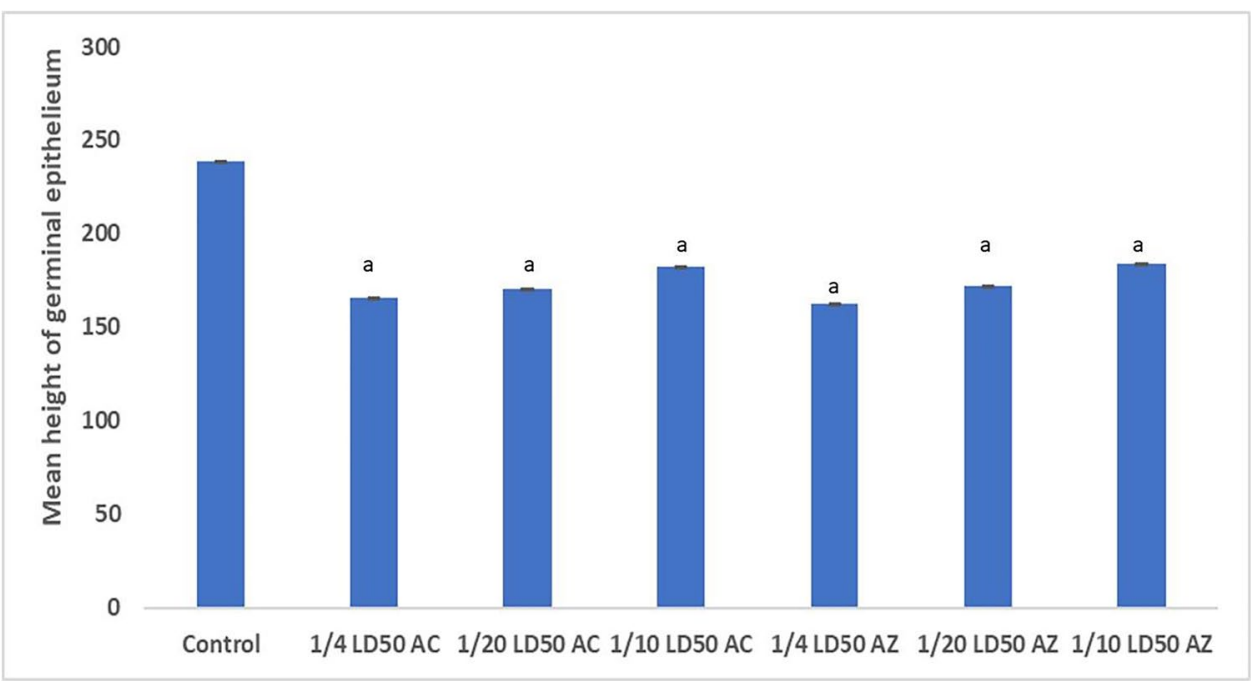


Testicular oxidative stress, for example, has been linked to pathological disorders including cryptorchidism, varicocele, and testicular torsion, as well as intoxicant exposures that are believed to damage male fertility (Turner and Lysiak 2008). Furthermore, phthalate inhibits the activity of enzymes involved in the synthesis of $\mathrm{H}_{2} \mathrm{O}_{2}$, resulting in changes in the activity of enzymes involved in the degradation of $\mathrm{H}_{2} \mathrm{O}_{2}$ (Arteel 2003).

Previous research suggested that AC's effects occurred by elevation of oxidative stress, as it raised LPO and NO levels in the testes and decreased CAT activity (Mondal et al., 2019). In the same line as the previous explanation, AC and AZ increase NO levels and cause depletion of SOD, CAT, and GR at different doses. This change may be the result of the body's defensive mechanisms attempting to deal with the issue, resulting in a disruption of most biological functions and parameters. During the previous biochemical studies, there were significant changes in male rats' serum overall antioxidant levels during cypermethrin treatments (Bhushan et al., 2013). Biphenyl amine also caused significant alterations in antioxidant enzyme levels (Moustafa and Ahmed 2016). Moreover, exposure to AC resulted in a significant decrease in the levels of SOD and CAT activities with a concomitant increase in the LPO of the liver (Chakroun et al., 2016).

Our data show that AC treatment causes oxidative stress and increases serum NO levels. The antioxidant defense system's failure to eliminate ROS influx is evidenced by the overproduction of ROS and a decrease in SOD and CAT. The consumption of this enzyme in eliminating toxins may explain the reduced activity of SOD in the serum to remove $\mathrm{O}_{2}{ }^{-}$into $\mathrm{H}_{2} \mathrm{O}_{2}$ while CAT, a ubiquitous enzyme, scavenges $\mathrm{H}_{2} \mathrm{O}_{2}$ into water and oxygen (Tang et al. 2006). However, the activity of these antioxidant enzymes involved in free radicals may be changed during these processes, resulting in a buildup of $\mathrm{H}_{2} \mathrm{O}_{2}$ in the cell membrane, which promotes LPO.

$\mathrm{NO}$ is a free radical produced by nitric oxide synthase (NOS) enzymes during catalytic oxidation. Long-term NO exposure reflects badly on tissue structure and integrity (Paul et al. 2016). This is due to the interaction of $\mathrm{NO}$ with $\mathrm{O}_{2}$ to produce reactive nitrogen oxide species like $\mathrm{NO}_{2}$ and $\mathrm{N}_{2} \mathrm{O}_{3}$, or with superoxide anion $\left(\mathrm{O}_{2}\right)$ to produce highly reactive peroxynitrite $\left(\mathrm{ONOO}^{-}\right)$, which can induce thiol oxidation or nitrosylation, tyrosine residue nitration, lipid, protein, and DNA oxidation (Abdel-Salam et al. 2017). The neurotoxic consequences of acute malathion poisoning in rats were related to increased endogenous NO production in the brain. In this study, we sought to see what role endogenously produced NO plays in the development of oxidative stress and neuronal damage caused by $\mathrm{AC}$ and $\mathrm{AZ}$. The current findings strongly imply that excessive NO is produced by iNOS during $\mathrm{AC}$ and $\mathrm{AZ}$ intoxication.

Both dosages of AC and AZ significantly decreased LH and FSH levels when compared to healthy controls. This finding was in line with Moustafa and Ahmed's (2016) findings, which demonstrated that long-term exposure to biphenyl amine at dosages of 50 and $200 \mathrm{mg} / \mathrm{kg} \mathrm{BW}$ induced significant alterations in sex hormones ( $\mathrm{LH}$ and FSH). A reduction in serum LH levels was also seen owing to the disrupter action of nonylphenol (González-Fernández et al. 2008; Aly et al. 2012).

The results of the study show that $\mathrm{AC}$ or $\mathrm{AZ}$ treatment has a histopathological impact on the rat's liver and testis. The liver and testis of the treated groups showed a series of histopathological symptoms after exposure to AC or AZ. The liver was affected more than the testis, according to the histopathological results. Insecticide AC caused far more hepatocellular damage in rats than the fungicide AZ, which is mostly due to its systemic toxicity and metabolites. Our data coincides with the observations of Mesnage and Antoniou (2018). Previous research demonstrated that AC is found at a higher level in the liver compared to the kidneys or testes (Zhang et al. 2011). Similar to our histological findings, AC is more toxic to the liver compared to the testis. Histopathological evaluations of the liver showed a dosedependent degenerative pattern.

Ziada and Abdulrhman (2020) reported that the AZ fungicide induced liver and kidney damage, as shown by the elevated function bioindicators. As a result of the AZ impact, GSH was reduced while MDA was increased dramatically. Aside from that, some tubular epithelial cells in the kidney were degenerating, there was hemorrhage, and the liver had an inflammatory cell infiltration.

As a result, the dose-response relationship was established in this study. The present study is complementary to Mondal et al. (2019) who reported that mild degenerative changes were observed in the liver of rats that received $25 \mathrm{mg} / \mathrm{kg}$ of AC, but the rats treated with 100 and $200 \mathrm{mg} / \mathrm{kg}$ showed severe liver fatty changes and necrosis, respectively. Also, in the present study, increased eosinophilia led to the lysis of hepatocytes.

The tissues showed hemorrhage, which seemed to be an allergic reaction to pesticides. The inflammatory response includes the migration and activation of both resident and circulating inflammatory cells, as well as the release of cytokines. Activated inflammatory cells and released cytokines induce fibroblasts to replicate, migrate, secrete and produce collagen (Ziada and Abdulrhman 2020).

Moreover, Mondal et al. (2019) reported that some chemicals may cause hepatocellular necrosis, rapid disorganization of the hepatic architecture, breakdown of sinusoidal structures, and pooling of blood in the liver through these mechanisms.

The testes of animals given AC or AZ show considerable degeneration of spermatogenic cells. Many researchers (Cao et al. 2019; Arican et al. 2020; Ibrahim et al. 2020) have recorded that $\mathrm{AC}$ or $\mathrm{AZ}$ affects the testicular histological structure, as well as spermatogenesis degeneration and sperm 
reduction. Also, Kong et al.'s (2017) study corresponds with the current data. Rats treated with AC ( $30 \mathrm{mg} / \mathrm{kg}$ BW for 35 days) showed that seminiferous tubules were impaired and had vacuolization as well as the number of interstitial Leydig cells decreased. In rat testes treated with $\mathrm{AC}\left(1 / 10 \mathrm{LD}_{50} / 30\right.$ days $)$, there was sloughing of spermatogenic cells, edema, a reduction in the number of sperm, and congestion (Keshta et al. 2016).

After 2 months of increasing the doses of AC and AZ, the rat sperm count and motility were dramatically reduced. This finding was previously recorded during a study of rats exposed to cyclophosphamide, which showed substantial differences in sperm count and morphology, as well as different effects on motility patterns (Shittu et al. 2019).

These biochemical elevations were confirmed by histopathological examinations as clear marked congestion, tubular cell degeneration, and sloughing of epithelial cells. Rats with reduced testosterone levels in their blood have less motile sperm after being exposed to AC (Halawa et al., 2021). This effect may be caused by oxidative stress, which disrupts the lipid bilayer in the cell membrane, resulting in decreased testosterone biosynthesis, which causes sperm motility, viability, and dysfunctional sperm to decrease. Insecticides have also been indicated in previous studies to induce mitochondrial membrane impairment in Leydig cells and inhibit testosterone formation by reducing cholesterol transmission into the mitochondria and decreasing cholesterol transfer to pregnenolone in the cells, resulting in lower testosterone output. The AC-fed rats had fewer Leydig cells than usual diet-fed rats, which may explain why testosterone levels were reduced (Desai et al. 2017). Also, the nicotinic acetylcholine receptor (nAchRs) was activated by AC and suppressed gonadotropin activity, resulting in a hormonal imbalance that harmed sperm output (Ngoula et al., 2007).

In Sprague Dawley rats treated with $10 \mathrm{mg} / \mathrm{kg}$ and $30 \mathrm{mg} /$ $\mathrm{kg}$ doses, Kong et al. (2017) found that AC raises LH levels while decreasing testosterone levels and sperm count. In Kunming male mice, Zhang et al. (2011) found that $30 \mathrm{mg} /$ $\mathrm{kg} \mathrm{AC}$ reduced the intact acrosome rate of sperm and testosterone levels. In a study performed by Mosbah et al. (2018), Wistar rats dosed with $27 \mathrm{mg} / \mathrm{kg}$ AC by gavage (5 days per week) for 45 days showed a rise in body weight and a decrease in testis weight, sperm count, plasma testosterone content, and sperm motility.

According to Arcan et al. (2020), oral administration of $\mathrm{AC}$ at varying doses $(12.5,25$, and $35 \mathrm{mg} / \mathrm{kg}$ ) for 90 days resulted in a dose-dependent drop in sperm concentration and plasma testosterone levels. Gonadotropin-releasing hormone (GnRH), FSH, and LH levels were all higher in the low and medium-dose cohorts. AC, on the other hand, caused LPO and GSH degradation in the testes. In both the low and high dose groups, the AC induced apoptosis, and the proliferation index in the high dose group was significantly decreased. Finally, AC toxicity in the reproductive system of males resulted from high doses. The oxidative stress, hormonal disruptions, and apoptosis could be the reasons for AC and AZ's toxic effects.

\section{Conclusion}

Exposure to $\mathrm{AC}$ and $\mathrm{AZ}$ was found to induce liver and testes toxicity by increasing serum NO level and depletion of serum enzyme antioxidant activities (GSH, CAT, and SOD) and this was confirmed by histopathology of the liver and testes as well as the alteration in the hormonal level and sperm counting. Also, AC harmed sperm features, which influenced FSH and LH levels. The findings of this study might be beneficial in assessing the hazards of $\mathrm{AC}$ and $\mathrm{AZ}$ to reproductive health. As a result, because the effects of these pesticides are time and dose-dependent, their use should be restricted.

Author contribution All the authors have accepted responsibility for the entire content of this manuscript and approved its submission.

Heba N. Gad EL-Hak: She is the supervisor, concern on histological part, and write the draft of the paper.

Rasha A. Al-Eisa: She made the design of the experiment, write the draft of the paper, and financial support.

Lamia Ryad: Supervisor, made the chemical analysis and biochemical analysis, wrote the draft of the paper, and did the statistical analysis.

Ekramy Halawa: Made all the practical, financial support, and write the draft of the paper.

Nahla S. El-Shenawy: Supervisor, financial support, and revision of the paper.

All the authors contributed to each step in the project.

Funding This study is funded by the Taif University Researcher Supporting Project Number (TURSP-2020/112), Taif University, Taif, Saudi Arabia.

Availability of data and materials All the data are presented in the paper.

\section{Declarations}

Data statement The user data to support the findings of this study are available from the corresponding author upon request.

All authors have seen and approved the final version of the manuscript being submitted. They warrant that the article is the authors' original work, has not received prior publication, and isn't under consideration for publication elsewhere.

Ethics approval This experimental study was performed with the confirmation of the local ethics committee on the use and care for animal experiments at the Faculty of Science, Suez Canal University, Egypt (permit number: REC57/2021).

Informed consent All the authors agree about the participation and publication of the paper.

Conflict of interest The authors declare no competing interests. 
Open Access This article is licensed under a Creative Commons Attribution 4.0 International License, which permits use, sharing, adaptation, distribution and reproduction in any medium or format, as long as you give appropriate credit to the original author(s) and the source, provide a link to the Creative Commons licence, and indicate if changes were made. The images or other third party material in this article are included in the article's Creative Commons licence, unless indicated otherwise in a credit line to the material. If material is not included in the article's Creative Commons licence and your intended use is not permitted by statutory regulation or exceeds the permitted use, you will need to obtain permission directly from the copyright holder. To view a copy of this licence, visit http://creativecommons.org/licenses/by/4.0/.

\section{References}

Abdel-Salam OME, Youness ER, Mohammed NA, Yassen NN, Khadrawy YA, El-Toukhy SE, Sleem AA (2017) Nitric oxide synthase inhibitors protect against brain and liver damage caused by acute malathion intoxication. Asian Pac J Trop Med 10(8):773-786

Adamkovicova M, Toman R, Martiniakova M, Omelka R, Babosova R, Krajcovicova V, Grosskopf B, Massanyi P (2016) Sperm motility and morphology changes in rats exposed to cadmium and diazinon. Reprod Biol Endocrinol 14(1):42

Alia M, Horcajo C, Bravo L, Goya L (2011) Effect of grape antioxidant dietary fiber on the total antioxidant capacity and the activity of liver antioxidant enzymes in rats. Nutr Res 23(9):1251-1267

Aly HAA, Domènech Ò, Banjar ZM (2012) Effect of nonylphenol on male reproduction: analysis of rat epididymal biochemical markers and antioxidant defense enzymes. Toxicol Appl Pharmacol 261(2):134-141

Arıcan EY, Gökçeoğlu Kayalı D, Ulus Karaca B, Boran T, Öztürk N, Okyar A, Ercan F, Özhan G (2020) Reproductive effects of subchronic exposure to acetamiprid in male rats. Sci Rep 10(1):1-10

Arteel GE (2003) Oxidants and antioxidants in alcohol-induced liver disease. Gastroenterology 124(3):78-790

Bancroft JD, Gamble M (2013) Theories and practice of histological techniques. New York, London, and Madrid: Churchill Livingstone 7(12):2768-2773

Bhushan B, Saxena PN, Saxena N (2013) Biochemical and histological changes in rat liver caused by cypermethrin and beta-cyfluthrin. Arh Hig Rada Toksikol 64(1):57-67

Bond CE, Greenfield SA (2007) Multiple cascade effects of oxidative stress on astroglia. Glia 55(13):1348-1361

Butterfield, D. A. (2020). Brain lipid peroxidation and Alzheimer disease: synergy between the Butterfield and Mattson laboratories. In Ageing Research Reviews (Vol. 64, p. 101049). Elsevier Ireland Ltd.

Cao W, Song Y, Sui H, Cao P, Liu Z (2019) Analysis of individual and combined estrogenic effects of bisphenol, nonylphenol, and diethylstilbestrol in immature rats with mathematical models. Environ Health Prev Med 24(1):1-13

Çavaş T, Çinkiliç N, Vatan O, Yilmaz D (2014) Effects of fullerenol nanoparticles on acetamiprid induced cytotoxicity and genotoxicity in cultured human lung fibroblasts. Pestic Biochem Physiol 114(1): $1-7$

Chakroun S, Ezzi L, Grissa I, Kerkeni E, Neffati F, Bhouri R, sallem, A., Najjar, M. F., Hassine, M., Mehdi, M., Haouas, Z., and Ben Cheikh, H. (2016) Hematological, biochemical, and toxicopathic effects of subchronic acetamiprid toxicity in Wistar rats. Environ Sci Pollut Res 23(24):25191-25199
Chang H-SS, Choo K-HH, Lee B, Choi S-JJ (2009) The methods of identification, analysis, and removal of endocrine disrupting compounds (EDCs) in water. J Hazard Mater 172(1):1-12

Chelikani P, Fita I, Loewen PC (2004) Diversity of structures and properties among catalases. In Cellular and Molecular Life Sciences Cell Mol Life Sci. 61(2):192-208

Desai A, Sequeira JM, Quadros EV (2017) Prevention of behavioral deficits in rats exposed to folate receptor antibodies: implication in autism. Mol Psychiatry 22(9):1291-1297

Di Lorenzo M, Winge SB, Svingen T, De Falco M, Boberg J (2020) Intrauterine exposure to diethylhexyl phthalate disrupts gap junctions in the fetal rat testis. Current Research in Toxicology $1: 5-11$

Doltade S, Lonare M, Raut S, Telang A (2019) Evaluation of acetamiprid mediated oxidative stress and pathological changes in male rats: ameliorative effect of curcumin. Proceedings of the National Academy of Sciences India Section B - Biological Sciences 89(1):191-199

Dringen, R. (2005). Oxidative and antioxidative potential of brain microglial cells. In Antioxidants and Redox Signaling (Vol. 7, Issues 9-10, pp. 1223-1233). Mary Ann Liebert, Inc. 2 Madison Avenue Larchmont, NY 10538 USA.

EC, (European Commission). (2004). European Commission review report for the active substance acetamiprid. SANCO/1392/2001. 6 (February 2000), 1-34.

Eckfeldt JH (1999) Tietz Textbook of Clinical Chemistry. Transfusion 39(7):794-794

EFSA. (2010). Conclusion on the peer review of the pesticide risk assessment of the active substance azoxystrobin. EFSA Journal, 8(4).

Elshal MF, McCoy JP (2006) Multiplex bead array assays: performance evaluation and comparison of sensitivity to ELISA. Methods 38(4):317-323

EPA, U. (1997). US EPA - Pesticides - Fact Sheet for Azoxystrobin.

EU. (2010). Directive 2010/63/Eu of the European Parliament and the council of 22 September 2010 on the protection of animals used for scientific purposes.

González-Fernández C, León-Cofreces C, García-Encina PA (2008) Different pretreatments for increasing the anaerobic biodegradability in swine manure. Biores Technol 99(18):8710-8714

Halawa, E., Ryad, L., El-Shenawy, N. S., Al-Eisa R.A., EL-Hak, H. N. G. (2021). Evaluation of acetamiprid and azoxystrobin residues and their hormonal disrupting effects on male rats using liquid chromatography-tandem mass spectrometry. PLOS Biology. Accepted.

Halliwell, B. (2006). Oxidative stress and neurodegeneration: where are we now? In Journal of Neurochemistry (Vol. 97, Issue 6, pp. 1634-1658). John Wiley and Sons, Ltd.

Ham J, You S, Lim W, Song G (2020) Etoxazole induces testicular malfunction in mice by dysregulating mitochondrial function and calcium homeostasis. Environmental Pollution 263:114573

Ibrahim H, Banna S, Rafea A (2020) Acetamiprid, insecticide-induced oxidative damage on reproductive parameters male rats. Alexandria Journal of Veterinary Sciences 64(1):63

Kaneko, S., and Tomino, Y. (1999). Acute-chronic pyelonephritis. In Ryōikibetsu shōkōgun shirīzu (Issue 23 Pt 1, pp. 514-518). Ryoikibetsu Shokogun Shirizu.

Kanu, K. C., Ijioma, S. N., and Atiata, O. (2016). Haematological, Biochemical and Antioxidant Changes in Wistar Rats Exposed to Dichlorvos Based Insecticide Formulation Used in Southeast Nigeria.

Kapoor U, Srivastava MK, Srivastava LP (2011) Toxicological impact of technical imidacloprid on ovarian morphology, hormones, and antioxidant enzymes in female rats. Food Chem Toxicol 49(12):3086-3089 
Karaca BU, Arican YE, Boran T, Binay S, Okyar A, Kaptan E, Özhan G (2019) Toxic effects of subchronic oral acetamiprid exposure in rats. Toxicol Ind Health 35(11-12):679-687

Kenfack A, Guiekep AJN, Ngoula F, Vemo BN, Bouli FPNO, Pamo ET (2018) Reproductive toxicity of acetamiprid in male Guinea pigs (Cavia porcellus). Journal of Animal Science and Veterinary Medicine 3(4): 105-111

Keshta AT, Hataba AA, Mead I, H. M., and El-Shafey, N. M. (2016) Oxidative stress and biochemical changes induced by thiamethoxam and acetamiprid insecticides in rats. World Journal of Pharmacy 5(6):44-60

Kong D, Zhang J, Hou X, Zhang S, Tan J, Chen Y, Yang W, Zeng J, Han Y, Liu X, Xu D, Cai R (2017) Acetamiprid inhibits testosterone synthesis by affecting the mitochondrial function and cytoplasmic adenosine triphosphate production in rat Leydig cells. Biol Reprod 96(1):254-265

Mesnage, R., and Antoniou, M. N. (2018). Ignoring adjuvant toxicity falsifies the safety profile of commercial pesticides. Frontiers in Public Health, 5.

Mondal, S., Pradhan, S., and Mukhopadhayay, S. K. (2019). Alteration in behavior of rat after chronic exposure to acetamiprid.

Mosbah R, Djerrou Z, Mantovani A (2018) Protective effect of Nigella sativa oil against acetamiprid induced reproductive toxicity in male rats. Drug Chem Toxicol 41(2):206-212

Moustafa GG, Ahmed AAM (2016) Impact of prenatal and postnatal exposure to bisphenol A on female rats in a two generational study: genotoxic and immunohistochemical implications. Toxicol Rep 3:685-695

Naasri S, Helali I, Aouni M, Mastouri M, Harizi H (2021) N-acetylcysteine reduced the immunotoxicity effects induced in vitro by azoxystrobin and iprodione fungicides in mice. Environ Toxicol 36(4):562-571

Nazıroğlu, M. (2007). New molecular mechanisms on the activation of TRPM 2 channels by oxidative stress and ADP-ribose. In Neurochemical Research (Vol. 32, Issue 11, pp. 1990-2001). Springer New York.

Ng, V. (2002). Effects of Disease on Clinical Laboratory Tests, 4th Edition, Vol. 1 and 2. D.S. Young and R.B. Friedman, eds. Washington, DC: AACC Press, 2001, \$199.00 (\$159.00 AACC members), softcover. ISBN 1-890883-45-X. Clinical Chemistry, 48(4), 682-683.

Ngoula F, Watcho P, Dongmo MC, Kenfack A, Kamtchouing P, Tchoumboue J (2007) Effects of pirimiphos-methyl (an organophosphate insecticide) on the fertility of adult male rats. Afr Health Sci 7(1):3-9

Nilius B, Owsianik G, Voets T (2008) Transient receptor potential channels meet phosphoinositides. EMBO J 27(21):2809-2816

Okwakpam FN \& Monanu MO (2020) Evaluation of stress enzymes activities and lipid peroxidation in heart homogenates of male albino rats following the administration of diclofenac. Asian Journal of Research in Biochemistry 6(3):10-16

Patlevič P, Vašková J, Švorc P, Vaško L, Švorc P (2016) Reactive oxygen species and antioxidant defense in human gastrointestinal diseases. Integrative Medicine Research 5(4):250-258

Paul C, D. S., Carvalho, A. F., and McIntyre, R. S. (2016) Nitric oxide and major depressive disorder: pathophysiology and treatment implications. Curr Mol Med 16(2):206-215

Pohanish RP (2015). A. In Sittig's Handbook of Pesticides and Agricultural Chemicals (pp. 1-53). Elsevier.
Pouech C, Tournier M, Quignot N, Kiss A, Wiest L, Lafay F, FlamentWaton MM, Lemazurier E, Cren-Olivé C (2012) Multi-residue analysis of free and conjugated hormones and endocrine disruptors in rat testis by QuEChERS-based extraction and LC-MS/MS. Anal Bioanal Chem 402(9):2777-2788

Report AI (2014) Excavations at caerau hillfort, Cardiff, south wales, 2014 An Interim Report (Issue 35)

Riris ID (2017) Methoxy bergenin's effect on total protein, albumin and globulin levels of wistar rats' blood. Jurnal Der Pharma Chemica 9(13):90-94

Ritskes-Hoitinga M, Tobin G, Jensen TL, and Mikkelsen LF (2012) Nutrition of the Laboratory Mouse. In The Laboratory Mouse (pp. 567-599). Elsevier Ltd.

Rives C, Fougerat A, Ellero-Simatos S, Loiseau N, Guillou H, GametPayrastre L, Wahli W (2020) Oxidative stress in NAFLD: Role of nutrients and food contaminants. Biomolecules 10(12):1-69

Rodrigues ET, Lopes I, \& Pardal MÂ (2013) Occurrence, fate and effects of azoxystrobin in aquatic ecosystems: a review. Environ int 53:18-28

Ronis MJ, Watt J, Pulliam CF, Williams AE, Alund AW, Haque E \& Robertson LW (2020) Skeletal toxicity resulting from exposure of growing male rats to coplanar PCB 126 is associated with disruption of calcium homeostasis and the GH-IGF-1 axis and direct effects on bone formation. Arch toxicol 94(2):389-399

Shittu SA, Shittu ST, Akindele OO, Kunle-Alabi OT, Raji Y (2019) Protective action of n-acetylcysteine on sperm quality in cyclophosphamide-induced testicular toxicity in male Wistar rats. Jornal Brasileiro De Reproducao Assistida 23(2):83-90

Tang Y, Kukita T, Ushijima Y, Kukita A, Nagata K, Sandra F, Rasubala L (2006) Regulation of osteoclastogenesis by Simon extracts composed of caffeic acid and related compounds: in rats". Histochem Cell Biol 125(3):215-225

Terayama H, Qu N, Endo H, Ito M, Tsukamoto H, Umemoto K, Kawakami S, Fujino Y, Tatemichi M, Sakabe K (2018) Effect of acetamiprid on the immature murine testes. Int J Environ Health Res 28(6):683-696

Turner, T. T., and Lysiak, J. J. (2008). Oxidative stress: a common factor in testicular dysfunction. In Journal of Andrology (Vol. 29, Issue 5, pp. 488-498).

Uboh FE, Akpanabiatu MI, Ndem JI, Alozie Y, Ebong PE (2009) Comparative nephrotoxic effect associated with exposure to diesel and gasoline vapours in rats. Journal of Toxicology and Environmental Health Sciences 1(4):68-074

Williams M (2013) The Merck index: an encyclopedia of chemicals, drugs, and biologicals. Drug Dev Res 74(5):339-339

Zhang, Wang, Y., Xiang, H., Li, M., Li, W., Ma, K., Wang, X., and Zhang. (2011). Oxidative Stress: role in acetamiprid-induced impairment of the male mice reproductive system. Agricultural Sciences in China, 10(5), 786-796.

Ziada RM, Abdulrhman SM (2020) Hepato-Nephro-Toxicity Induced by Premium Fungicide and Protective Effect of Sesame Oil in Male Rats 81(October):2445-2450

Publisher's note Springer Nature remains neutral with regard to jurisdictional claims in published maps and institutional affiliations. 